\title{
Prevention of Radicalism in the Cyberspace in Indonesia
}

\author{
Syarif Saddam RivanieParawansa ${ }^{1^{*}}$, Koesrianti ${ }^{2}$, Toetik Rahayuningsih ${ }^{2}$ \\ ${ }^{1}$ Ph.D. Student, Doctoral Program, Faculty of Law, Universitas Airlangga \\ ${ }^{2}$ Assoc. Professor, Faculty of Law, Universitas Airlangga
}

*Corresponding Author: Syarif Saddam RivanieParawansa, Ph.D. Student, Doctoral Program, Faculty of Law, Universitas Airlangga

\begin{abstract}
Nearly two decades after the devastating Bali bombing, terrorism still remains at the core of Indonesian national security. The government has programs on counterterrorism in order to eradicate terrorist attacks. A national auxiliary body,National Counter Terrorism Agency or Badan Nasional Penanggulangan Terorisme (herein after BNPT) has been established in 2010 with the main duty to eradicate terrorism in Indonesia with some strategic policies which consist of legal enforcement and anticipatory measures. However, terrorist attacks had occurred again in 2018 in Surabaya. This condition would have become worsened with the existence of digital media. By its nature, the Internet provides more opportunities for individuals to become radical since the Internet can give almost unlimited information including radicalism that nearly without filter from various sources. This paper is normative legal research with conceptual, historical, and statute approaches by which the result of this paper can be used as a reference for the government in eliminating digitalized radicalism in Indonesia. This paper argues that the Internet as one method of communication devices may become a very dangerous method of radicalization in Indonesia, in this case, self-radicalization because individuals may communicate and collaborate with terrorists and extremists who stay in other countries without physical contact. In this respect, radicalism would have spread easily and massive in Indonesia with the target of youth as the biggest user of digital social media. This paper analyzes de-radicalization programs by Indonesian government to stem the tide of radicalism that leads to terrorism including international cooperation in the Southeast Asian region as the ASEAN member states would like to build resilience against potential disruptive effects of digital revolution 4.0.
\end{abstract}

Keywords: de-radicalization, internet, counterterrorism, Indonesia, BNPT.

\section{INTRODUCTION}

Indonesia is 'Negara hukum' or a state that based on law, as stipulated in Article 1 paragraph 3 of the 1945 Constitution of the Republic of Indonesia (hereinafter the 1945 Constitution RI or UUD NRI 1945). Article $28 \mathrm{~F}$ of the 1945 Constitution RI states that every person has the right to communicate and obtain information to develop their personal and social environment which means that every person has the right to obtain pieces of information from everywhere and at any time, and exploit it for fulfillment of the everyone' need of information in the community, nation, and state. Information is every person's main need for personal and social environment development. In addition, obtaining information freely is also one of the important characteristics of a democratic state that state upholds the sovereign of its people. ${ }^{1}$

Nowadays, information can be obtained by face-to-face mechanism and through the Internet or virtual world. With the help of the Internet, personal ideas can turn into public consumption when they are posted on the mass timeline and become mass conversations. With the Internet, the world has become borderless where it seems there are no partitions and distances among people and in fact, it is often difficult to distinguish between public and private areas simultaneously. With the changes in communication and interaction media that have been included in the digitalization vortex like this age, we seem to have no choice but to get in and actively participating in it. People prefer to disseminate

*Thia is the revised article that has been presented at International Conference on Law and Society 8 (ICLAS 8) 2019 "Law in the Digitalization Era", 6-7 April 2019 at Fatih Sultan Mehmet Vakif University Halic Campus in Istanbul, Turkey.

${ }^{1}$ Preamble of the Law Number 14 Year 2008 on Disclosure Public Information 
information through the Internet such as social media, as it has been constituted as a powerful way of communication because it is more right on target, faster and interactive, practical, trendy, up to date and popular. Demographically, the majority of users of social media are the young generation. In this context, the spread of radicalism not only can be done through face-to-face meetings but also through the Internet. Indeed, the Internet is considered as a powerful and effective way in spreading radical notions regardless the disseminator' location is very distant and the whereabouts is quite hard to determine. Besides that, the Internet is considered to have many advantages, including easy to access, has wide audiences, anonymity, fairly fast information flow, can be used as an interaction medium, inexpensive, multimedia in the form of print, sound, picture and video, as well as a mainstream media in the millennial era. The Internet, however, lacks control and binding regulations which tend to be misused.

Indriyanto Seno Adjiasserts firmly that terrorism is constituted as an extraordinary crime that damaging the unity of state concerning with economy, society, and culture. Terrorism also has killed innocent civilians, obstruct integrity and district state' facilities whether public or social ones. The motives underlying the emersion of terrorism vary, which includepolitical, religion, and ideology motives, vengeance, Madness, economic and legal factors. ${ }^{2}$ The other motives are the use of force and the creation of psychological pressure for certain purposes. ${ }^{3}$ The new style of terrorism can attack anyone, anytime and anywhere. Terrorist attacks are carried out usually in crowded places such as malls, worship places, campuses, schools, and many others.

In 2003, the Indonesian government issued Law No. 15 of 2013 concerning the Enactment of Government Regulation in Lieu of Law No. 1 of 2002 (State Gazette of the Republic of Indonesia of 2003 No. 45, Supplement to the State Gazette of the Republic of Indonesia Number 4283 concerning the Eradication of Crime of Terrorism) which was promulgated on April 4, 2002. Theenactment of this terrorism regulation responded totwo extraordinary terrorist bombing attacks that had killed hundreds of innocent peoplein the Kuta and Legian, Bali. It can be said that law should be developed to go along with the development of society, so the government amended the terrorism regulations became Law No. 5 of 2018 concerning The Eradication of Terrorism Crime, (State Gazette of the Republic of Indonesia Year 2018 Number 92, Supplement to the State Gazette of the Republic of Indonesia Number 6216).

The substance of this new law includes provisions on the prevention of terrorism criminal acts called a de-radicalization program. Actually, this program has started since 2011 initiated by the National Counter Terrorism Agency (hereinafter BNPT) which was established based on Government Regulation Number 46 of 2010. The main task of BNPT is to prevent the spreading of terrorism in Indonesia through the de-radicalization program which some of the programs are carried out through virtual world or in cyberspace along with other programs that are conducted in a conventional way in prison.

Deradicalization simply can be defined as a systematic effort to transform or metamorphose radicalism and eventually it would have eradicated radicalism. Thus, de-radicalization in the virtual world can be defined as a systematic cyber effort that aims to transform the radical virtual world into de-radical cyberspace that consists of counter-terrorism contents which can be consumed by the Internet users. One example of the cyber de-radicalization program which runs by BNPT is the website called DamailahIndonesiaku.com, which contains the correct information on various ideologies and beliefs that have known in Indonesia and related issues. In this context, this article aims to discuss the spreading of radicalism in the digitalized era in Indonesia, with emphasis on the problems and its possible solution to eradicate radicalism. After the description of the characteristics of ICT and its development, this article examines the root problems of radicalism which then follows by the discussion on the characteristics of terrorism, particularly in the digitalized era. This article analyses the radicalism in Indonesia especially its focus on its spreading and the prevention programs which include the ASEAN cooperation and cybersecurity. Lastly, this article draws a conclusion with some feasible solutions to eradicate cyber terrorism in Indonesia.

\footnotetext{
${ }^{2}$ Zulfadli.2017. Radikalisme Islam dan Motif Terorisme di Indonesia. Vol. 22, Jurnal Akademikap.189-191

${ }^{3}$ Amien Rais, 'Hadapi Terorisme dengan Cerdas', <http://ahmad.web.id/sites/kolom_amien_rais/20021031105455.shtml>, accessed 29 October 2018
} 


\section{DISCUSSION}

\subsection{Characteristics of Information Technology and its Development}

The Internet has changed the orientation of peopleconcerning lifestyle, behavior, habit, and opinions. Indeed, the current sophisticated internet technology certainly has both positive and negative impacts. Positive impact if the technology is used for the general benefit while negative impact if it is used for creating damage in the surrounding environment. Based on the Wearesocial report, there were a few astonishing facts, among them is the number of world internet users are 4,021 billion people approximately, which means that half of the human in Earth have used the internet. Indonesia itself in the term of internet usage ranked fourth in the world as the largest and most active internet user with a duration of about 8 hours 51 minutes. The first rank of the world is Thailand which has a duration of using the internet for 9 hours 38 minutes, second place in the Philippines for 9 hours 29 minutes, and Brazil with a duration of 9 hours 14 minutes. While the developed countries such as Singapore only about 7 hours 9 minutes, China 6 hours 30 minutes, United States 6 hours 30 minutes and Germany 4 hours 52 minutes. ${ }^{4}$

Whereas according to the Report of the Indonesian Internet Service Provider Association (hereinafter abbreviated as JP II) in obtaining information, throughout 2017 the population of Indonesia which currently reaches 262 million people, 143 million of them or more than 50 percent have been connected to the internet in obtaining information. Indonesia, which is divided into 5 major islands, namely Java, Kalimantan, Sumatra, Sulawesi, and Maluku Island, are all connected to the internet network. The people of Java Island access information most often through the internet, 57.70\%, followed by Sumatra $19.09 \%$, Kalimantan $7.97 \%$, Sulawesi $6.73 \%$, Bali and Nusa Tenggara 5.63\%, and Maluku Papua $2.49 \% .^{5}$

As many as $49.52 \%$ of internet users in Indonesia are those aged 19 to 34 years, usually called millennials. It is these millennials who access information the most through social media in the form of Facebook, Instagram, YouTube, Twitter, and others. Indonesia itself is ranked third in the world as the most active country accessing social media through mobile phones with a growth rate of 24 million users or 23 percent, after the United States and Brazil. ${ }^{6}$ Furthermore, $29.55 \%$ of internet users in Indonesia are 35 to 54 years old, then adolescents ages 13 to 18 rank third with $16.68 \%$. And finally, elders age 54-year-old only $4.24 \%$.

The high use of the internet related to the increasing use of mobile phones. According to the EMarketer Report, the use of mobile phones from 2009 to 2018 has reached 100 million smartphone users in Indonesia. ${ }^{7}$ The digital age also has advantages and disadvantages in disseminating information. The advantages, namely : First, make it easier for someone to get unlimited information. A person can access information anytime and anywhere without having to bother to meet face to face. Second, disseminate information through the digital does not need to use a large room. Third, the information obtained is faster and more accessible to various groups. The shortcomings in the dissemination of information in this digital era, namely First, cannot be held accountable for who is spreading the information. Second, internet users become lazy to meet face to face with people. The biggest site blocked is social media Instagram and YouTube. ${ }^{8}$

In fighting fake news or hoaxes and preventing the spread of false news whether it is the spread of radicalism, the Indonesian Government has a sufficient legal, as stipulated in Article 28 paragraph 1 and paragraph 2 of Constitution No. 11 of 2018 concerning Information and Electronic Transactions as amended in Constitution No. 19 of 2016 concerning Information and Electronic Transactions. Article 390 of the Criminal Code also regulates hoaxes spreader.

\footnotetext{
${ }^{4}$ Bagus Ramadhan, 'Inilah Perkembangan Digital Indonesia Tahun 2018',<https://www.goodnewsfrom indonesia.id/2018/02/06/inilah-perkembangan-digital-indonesia-tahun-2018>, accessed 28 September 2018

${ }^{5}$ Fatimah Kartini Bohang, 'Berapa Jumlah Pengguna Internet di Indonesia' $<$ https://tekno.kompas.com/read/ 2018/02/22/16453177/berapa-jumlah-pengguna-internet-indonesia>, accessed 27th Januari 2019)

${ }^{6}$ Bagus Ramadhan, Op.Cit, Inilah Perkembangan Digital Indonesia Tahun 2018.

${ }^{7}$ Harso Kurniawan, '2018 Pengguna Smartphone Capai 100 Juta Orang', <https://id.beritasatu.com/home/2018pengguna-smartphone-capai-100-juta/176965>. accessed 17 January 2019)

${ }^{8}$ Anonim, 'Pemerintah Blokir Ribuan Situs Radikal', <https://www.validnews.id/Pemerintah-Blokir-RibuanSitus-Radikal-cCk>, accessed January 16th, 2019
} 


\subsection{Radicalism and Characteristics of Terrorism in the Digitalized Era}

Currently, the internet is used by radical terrorist groups. Used as an effective medium by radical terrorist groups in building new networks, increasing propaganda, and preparing action plans. The power of terrorists is no longer from an individual network but through network connections through globally connected media. Through this media, terrorist groups reach out to all realms anywhere and anytime. Terrorist groups not only disseminate radical ideas through websites but also via social media which are more often accessed by young people to get information such as Twitter, Instagram, WhatsApp, etc.

According to Agus Surya Bakti, cyber terrorism is also not a new term in the form of information or sites that spread propaganda. Rapid technological development also has a positive side and a negative side depending on the use. The spread of the radicalism via cyberspace occupies a large role in the spread of doctrines that have had seeds for the terrorist. ${ }^{9}$

Whereas radicalization occurs when a person is confronted with radical beliefs and ideas and a further process occurs, that belief makes the person implementing it in the form of action. At present, the presence of social media can be a tool to spread radical ideas more easily. Along with the times, in terms of the development of criminal acts of terrorism also influenced by other external factors. According to Hasnan Habib quoted from Budi Mulyana, the development of international terrorism can also evolve due to various supporting factors or the existence of assistance, training, weapons, information or propaganda, and other supporting factorsnamely ${ }^{10}$ :

- Given training can place or state-assisted, or in a third country, or in a country that helps;

- Other assistance, which can cause death, such as supplies of weapons, bombs, explosives, etc.;

- The assistance that is a supporting factor, such as transportation, communication, health, financial, legal assistance, harborage, important documents;

- Propaganda, in the form of information dissemination through social media, print media, various group organizations/intermediaries; and

- Dissemination of false information or hoaxes that cause provocation.

In addition, from various incidents of terror that occurred in this world, terrorism with a new form in the last ten years has several characteristics, ${ }^{11}$ namely: 1 ). there is the aim of maximizing the victim in a very terrible manner, 2) the desire to get coverage in the mass media internationally as quickly as possible, 3) when acts of terror have occurred, no one has ever made a claim against a terrorist act that has been committed, 4) the attack could never be expected because the target was the same as the entire surface of the earth.

A study conducted by Gabriel Weimann showed that terrorist group networks pay more attention to the use of cyberspace. This can be seen from the increasing number of sites regarding radical notions circulating in cyberspace. If in 1998 there were only 12 sites, by 2003 the site had reached 2,650 sites. And finally, in 2014 there were 9,800 sites managed by terrorist groups. ${ }^{12}$

Besides the spread of notion through the internet by people or communities, there are also terrorists who move on their own without an order. This is a type of terrorism that is very difficult to trace or detect early. Usually, these terrorists only utilize the internet to disclose the results of their actions in the real world, this individual is called a lone wolf terrorist. This type of lone wolf terrorist acts without having a direct link with a larger terrorist group, such as ISIS and Al-Qaeda. They don't have a network so these people are quite difficult to track and tracking the buying and selling online of someone who buys weapons, explosives, etc. The motivation of this type of terrorist is first, the existence of internal motivation or motivation that comes from oneself due to dissatisfaction with something in this world. In addition, there is also motivation from outside. Usually, the motivation

\footnotetext{
${ }^{9}$ Agus Surya Bakti, Teroris Merambah Dunia Maya, Kompas Newspaper, May 22th 2018, p.4.

${ }^{10}$ Budi Mulyana. 2013. Terorisme Internasional: Agenda Propaganda, Amerika Serikat dan Pandangannya Menurut Islam, Vol. 2Jurnal Ilmiah Ilmu Politik dan Komunikasi.p.4.

${ }^{11}$ Amien Rais, Loc.Cit,

12 Gabriel Weimann, Terror on the Internet: The New Arena, the New Challenges, United States : Institute of Peace, p.30
} 
from outside is people who are quite active in utilizing the internet or often interact with the outside world whether it's individuals or communities. ${ }^{13}$

\subsection{Radicalism in Indonesia: It's Spreading and Prevention}

The Radicalism has developed since before the existence of the internet, and is growing rapidly with the internet. Besides going through cyberspace, radicalism is also spread through hoaxes or fake news. ${ }^{14}$ Besides that, according to Septiaji Eko Nugroho, there are five ways that can help distinguish which hoax news and real news, that is ${ }^{15}$ :

$>$ Be careful with provocative titles

$>$ Pay attention to the address of the site

$>$ Check the facts

$>$ Check the authenticity of the pictures

$>$ Participate in anti-hoax discussions

Many people have difficulty choosing the information they receive even though not a little of the information they receive tends to develop an intolerant and radical attitude. The lack of knowledge also makes vulnerable people trapped as the perpetrator of the spread of false news consequently the faster false news spreading. To counteract hoaxes, the public can be involved as citizen journalism. ${ }^{16}$ By understanding the basics of journalism, people can be more selective in receiving information so that it is not easily provoked by false news. Journalists also have to play an active role in making back-up narratives of hoaxes that are already spread. Journalists are bound to a code of ethics as reporters/journalists who play an important role in verifying and providing clear information to the public. ${ }^{17}$

BNPT modules cited from Panji Futuh Rahman, that a person or community can be said to adhere radicalism if 1) Disobedience as citizens, 2) Unfaithfulness on Pancasila, 3) The desire to establish an Islam-based state, 4). Support for Sharia law, 5) Carry out jihad that does not comply with the rules of religion. ${ }^{18}$

\footnotetext{
${ }^{13}$ Jajang Jahroni dan Jamhari Makruf. 2016.Memahami Terorisme : Sejarah, Konsep, dan Model, Jakarta : Pusat Pengkajian Islam dan Masyarakat UIN Syarif Hidayatullah. p.155-156

${ }^{14}$ Hoax is fake information or news that can actually contain facts but has been twisted or engineered. However, the words of hoax are now increasingly used and pinned when addressing news that has absolutely no facts (fake news). To simplify the explanation of the differences between fake news and hoaxes, it can be illustrated as follows: In terms of fake news is hoax, artificial news or fake news that is not based on facts, reality or truth. While the term hoax is false information by changing facts or actual facts. The development of the word hoax from previous forms can be traced in the book "A Glossary: Or, Collection of Words, Phrases, Names and Allusions to Customs", written by Robert Nares, published in 1822 in London where the word hoax began to be used in England in the century -18. Robert Nares writes that hoaxes come from hocus, a Latin word that refers to hocus pocus. In entries (words or phrases entered in the dictionary along with a brief description) said hocus, Nares adds the meaning "to cheat" or "cheat". Hocus pocus according to Robert Nares refers to the magician spells that magicians then use when starting tricks. Hocus pocus is taken from the name of the famous Italian witch, Ochus Bochus. The definition of "cheating" is intended to confuse others for entertainment. In the sense that the deceived person does not feel harmed and understands he is being confused. In the book, Nares calls the mantra a strong confirmation of the origin of the word hoax.(Anonym, 'Pengertian Hoax dan Asal Kata Hoax', $<$ https://lenterakecil.com/pengertian-dan-asal-kata-hoax/>accessed 24 May 2019.

${ }^{15}$ Anonim, 'Ini Cara Mengatasi Berita Hoax di Dunia Maya', <https://kominfo.go.id/content/detail/8949/inicara-mengatasi-berita-hoax-di-dunia-maya/0/sorotan_media〉, accessed28 December 2018)

${ }^{16}$ Citizen journalism is a journalistic activity carried out by citizens or ordinary people who aim to spread the news. Citizen journalism has an active role in the process of collecting, reporting, analyzing, and disseminating news and information. As for terms other than the term citizen journalism, including public journalism, media participatory, citizens media, and others. The hoax news that often arises lately has implications for the number of people who are quickly affected by the news that cannot asked for trusted sources.(dikutip dari via Santha Oktabriancha, 'Mengenal Citizen Journalism (Jurnalisme Warga)',

<https://www.kompasiana.com/santhabriancha/58ca972e729373722f0e2a8c/mengenal-citizen-journalismjurnalisme-warga>. accessed 27 December 2018)

${ }^{17}$ Anonym, 'Paham Radikal Tersebar lewat Berita Bohong', Kompas Newspaper, May 19th, 2017, [5]

${ }^{18}$ Panji Futuh Rahman. 2016. 'Penerapan Materi Deradikalisasi untuk Menanggulangi Radikalisme'. Vol.3.JurnalTARBAWY, p.12
} 
In order to prevent the widespread of radicalism via the internet, the Indonesian Government through the Ministry of Communication and Information has blocked dozens of sites or websites that have and disseminate radical notions that are considered dangerous, there are several sites that have been blocked including, arrahmah.com, voa-islam.com, and hidayatullah.com. ${ }^{19}$ In simple terms, deradicalization is defined as a systematic effort to change or eliminate radicalism. According to Agus Surya Bakti, The definition of virtual world deradicalization means systematic efforts that want to change the virtual world which is currently filled with radical contents into not radical or fights the influence of radical content to not affect readers and users. ${ }^{20}$

The 2012 UN report entitled The Use of the Internet for Terrorist Purposes has seven objectives of terrorist groups in utilizing internet media, namely ${ }^{21}$ :

- Propaganda Media. The goal is to spread more widely. Ideological doctrines, instructions, explanations, justifications, and promotion of their activities and prowess. The media distribution also varies, both through virtual messages, presentations, magazines, audio, video, to game applications.

- Recruitment. The aim is not only to spread and promote violence, but also to establish relationships with the target audience. In establishing relationships with potential terrorist members, terrorist groups provide chat groups and forums.

- Incitement/invitation to act. The aim is that terrorist groups prepare various materials and files that can be downloaded and contain the call to commit acts of terror. Some sites also teach about how to assemble bombs, calls for violence, and other explosives.

- Funding. The aim is the internet as a source and tool for funding terror activities. Various methods are used to make the internet a source of funding, namely 1) requests for direct assistance, such as through websites, social media, chat rooms and requests for donations from supporters, 2) $e$ commerce, make an online shop by offering books, audio, merchandise, and other items to its supporters.

- Training. The internet is widely used by terrorist groups as a training ground. Many sites, blogs, social media that disseminate practical guidance in the form of logbooks, videos, and audio.

- Planning. The internet is very useful as a means of communication to develop action plans. Through the internet, terrorist groups are also able to formulate strategies, target attacks, and others by using secret messages.

- Cyberattack. The goal is to attack computer systems, servers, the spread of viruses, malware, and other cyber threats.

A study from the Ministry of Communication and Information in collaboration with UNICEF UN and Berkman Center for Internet and Society, Harvard University, in 2014, that 98 percent of children and adolescents in Indonesia know about the internet and 79.5 percent of them are active internet users. In fact, this is a chance for terrorist groups to recruit potential terrorists from among young people. ${ }^{22}$

In the current internet era, the process of disseminating radical ideas is faster, wider reaching, and quite difficult to detect who is the 'actor' behind. The dissemination of this notion is no longer carried out from top to bottom (bottom-up), but allowed to spread by itself (via the internet). Marc Sageman once noted that the main factor in the dissemination of radicalism is face to face interaction and the closest part is family ties and friendship, but this factor is no longer strong enough to be the main factor. The spread of radicalism through the internet is a major factor for faster spreading. ${ }^{23}$

\footnotetext{
${ }^{19}$ Anonym, 'BNPT Minta Kominfo Blokir 22 Situs Radikal', <https://kominfo.go.id/index.php/content/detail/ 4627/BNPT+Minta+Kominfo+Blokir+22+Situs+Radikal/0/berita-satker>, accessed 27 November 2018)

${ }^{20}$ Agus Surya Bakti, Op.Cit,Deradikalisasi Dunia Maya, [86]

${ }^{21}$ Dokumen UNODC. 2012.'The Use of the Internet for Terrorist Purposes', UNODC (United Nation Office on Drugs and Crime), 2012, p. 3-12

22 Anonim, 'Riset Kominfo dan UNICEF Mengenai Perilaku Anak dan Remaja Dalam Menggunakan Internet', $<$ http://kominfo.go.id/index.php/content/detail/3834/Siaran+Pers+No.+17-PIH-KOMINFO-2-

2014+tentang+Riset+Kominfo+dan+UNICEF+Mengenai+Perilaku+Anak+dan+Remaja+Dalam+Menggunakan +Internet>, accessed 25 July 2018).

${ }^{23}$ Philip Seib and Dana M. Janbek,2012.Global Terrorism and New Media: The Post Al-Qaeda Generation, New York : Roudledge, p.19
} 
Agus Surya Bakti cited from Gordon Graham mentioned that internet has 2 main characteristics: First, worldwide, the internet has the ability to be present in almost all corners of the world, because it can spread very quickly and without partition, and can be accessed by anyone and anywhereSecondly, it is popular, knows no social strata whether poor or rich, all can access the internet quickly and easily. ${ }^{24}$ The act of spreading radicalism of terrorism which so far from people or groups to the dissemination of ideas through the internet has made this method effective in recruiting new members.

In the dissemination of radical ideas through the internet, can be seen from sites that contain content about radicalism, as for the characteristics of sites that spread radicalism, are 1) usually adhering to religious notions (takhfiri). They often blame others who are not in line with their ideology and call them infidels, 2) Radical sites often provide incitement content to hate or hostile to the other party. Other parties referred to by Shia, Ahmadiyya, 3). justifying violence in the name of religion. One of them is jihad, 4). Radical sites besides puritans and rigid also teach their readers to reach the desired target with a fast and massive system. ${ }^{25}$ In preventing the spread of radicalism, an effort is needed, namely blocking sites that contain radical notions to stop the spread of radical ideas.

Based on observations from BNPT, in general, radical media have distinctive characteristics, namely ${ }^{26}$ :

- dissemination of ideas delivered freely and uncontrollably,

- the nature of radical media touches the subconscious and the reason of society religiosity,

- the workings of issue management appear to be radical movements through highly organized and systemic sites

- access to radical sites dominated by young people, but basically the virtual world can be accessed by everyone, knows no social strata, age, occupation, etc..

The technique of radicalism operations commonly carried out by terrorists in cyberspace, $\mathrm{i}^{27}$ :

- destroying the reputation of the scholars who are not in line with radical ideas with slander and accusations in cyberspace

- mutual infidelity of other groups

- people of other religions became their hate attacks

- radical groups always make the oppression of Muslims in the world the main reason

- solicitation against the government and its accomplices who are considered unjust

- propaganda is done by releasing images, memes, videos, and calls in the form of releases.

- Campaigning for hostility towards western countries which are considered to injure and slaughter Muslims.

Cyberwar, conducted by groups in cyberspace, has three major agendas, namely: 1) disseminating and attacking the mindset and paradigm of cyberspace users to participate with their 'struggles', at least sharing their thoughts, 2). Conduct cyber attacks directly on the government and state security forces in cyberspace, 3) hacking sites and banking and trading systems. The background of this motive is funding the terrorist movement.

Terrorism crime is a transnational crime which is a crime that covers several state jurisdictions. Therefore, the cooperation of countries is needed in quelling terrorism crimes. This is increasingly important because lately terrorism crimes have been committed by misusing information communication technology (ICT) or the internet. In today's digital era terrorism finds new ways to attack their targets, namely cyberterrorism, which has become a concern of many parties. Radical movements including terrorist groups have used internet access to support their movements, such as for example, member recruitment, propaganda, fundraising, cyber attacks, and others. This is a negative impact of internet use, especially by extremist groups, radicals, and terrorists. This group

\footnotetext{
${ }^{24}$ Agus Surya Bakti, Deradicalization of Dunia Maya, Jakarta: Daulat Press .p.81-82

${ }^{25}$ Ibid,p. $97-99$

${ }^{26}$ Ibid,p.100-102

${ }^{27}$ bid,p. $108-110$
} 
utilizes the sophistication of internet and social media services that can be used to control information on their organizations. Therefore we need a kind of protection and understanding for internet users in the ASEAN region, including Indonesia from the government as a strategy to overcome cyber attacks. Indonesia continues to collaborate with other countries and international organizations in mitigating cyber terrorism to advance state security. Cooperation with ASEAN countries is needed, in the form of a standard ASEAN Cyber Security Framework in preventing cyber-terrorism through the internet.

In ASEAN, the ASEAN Plan of Action (PoA) has been established to prevent and counter the rise of radicalism and violent extremism (2018-2025). This PoA aims to strengthen closer cooperation between ASEAN countries in preventing and countering the rise of radicalization and violent extremism. One of the priority areas of ASEAN is the prevention of radicalization and extremist movements in a way "strengthen strategic communications, including through the internet and social media to prevent their misuse by radicals and extremist proponents to pursue violent/extremist activities and promote extreme ideologies". ${ }^{28}$ In the national scope, a number of countries have formed a national body for cybersecurity purposes. Indonesia, for example, has inaugurated the establishment of The National Cyber and Encryption Agency (BSSN), in May 2017 which has the task of implementing national cybersecurity effectively and efficiently by using, developing and consolidating all elements related to cybersecurity. This BSSN is directly responsible to the president and is the main institution responsible for cybersecurity.

In addition, in preventing and overcoming cyber terrorism crimes, cooperation is needed in the development of Cyber Security frameworks among countries. This is considering that activities on the internet or cyberspace is a borderless global domain, does not require much space, and timeless so that this brings new challenges in the current era of information globalization. The inequality of understanding and definition of cyberspace in international society is an obstacle, challenge, and resistance when for example a country tries to make claims unilaterally over cyberspace as part of its national sovereignty. Because of this nature, terrorism cybercrime is categorized as a transnational cybercrime. So that cooperation from countries is needed in tackling and preventing this type of crime. For this purpose, there has been a proposal to utilize an internet security framework, namely The Six-Ware Cyber Security Framework (The SWCSF) for cyber cooperation in ASEAN. ${ }^{29}$ The SWCSF concept is a comprehensive concept for cybersecurity to improve network security in ASEAN countries from various threats, attacks, and vulnerabilities including terrorist and extremist attacks.

There has been an important agenda for cybersecurity cooperation among the ASEAN Member States (AMS) that there is an urgent need for AMS to continue and maintain their commitment to implement three important agendas, namely: ${ }^{30}$ first, identifies and applies behavioral norms in the use of information and communication technology in cyberspace. This can be done by referring to voluntary, non-binding norms, rules or principles of responsible behavior of states agreed at the 2015 UN Group of Government Expert (UN GGE) meeting. These norms and principles, even though they are nonbinding, can prevent conflict and maintain world security and peace. Examples of such norms are not carrying out or supporting activities that attack important information systems infrastructure, helping each other in the face of cyber attacks, and not deliberately allowing the territory of their country to launch cyber attacks. Second, increased Confidence Building Measures (CBM) among ASEAN countries. CBM is carried out through transparency and improvement of the dialogue mechanism between member countries. In addition, sharing the best experiences between member countries, and domestic policy transparency in the use of ICT. The third is capacity building in the field of cybersecurity among ASEAN countries. Every country has an obligation to protect its ICT national network. But not all ASEAN member countries have the same capacity. So that the government needs

\footnotetext{
${ }^{28}$ ASEAN, 'ASEAN Plan of Action to Prevent and Counter the Rise of Radicalisation and Violent Extremism', $(2018-2025)$

${ }^{29}$ Rudy Agus Gemilang Gultom, Asep Adang Supriyadi, and Tatan Kustana, 'Strengthening ASEAN Cyber Cooperation in Countering Cyber Terrorist Groups Activities on the Internet by Implementing the Six-Ware Cyber Security Framework (SWCSF)', (2018) 13 International Journal of Management and Information Technology, Issue 1,[3295]

${ }^{30}$ M. Chandra W. Yudha, 'Penguatan Kerja Sama Cybersecurity: Keniscayaan Untuk ASEAN, Masyarakat ASEAN' (Majalah) Direktorat Kerjasama ASEAN, ASEAN Goes Digital, Edisi 19 Agustus 2018, p.7
} 
to reduce the ICT capacity gap among countries towards ASEAN as a resilient community against cyber attacks.

\section{CONCLUSION}

The spreading of radicalism in Indonesia is continuing to grow fast thanks to the existence of the internet. The sophisticated of the internet and social media services have been used for the activities of radical movements including terrorist groups to support their radical actions, for example, for recruiting new members, propaganda, fundraising, cyber attacks, and others. The Indonesian government has some programs to prevent the spread of radicalism. The Government of Indonesia through the Ministry of Communication and Information has blocked accounts spread on the internet either through social media or sites or websites that have the potential to put the national security of the Republic of Indonesia. The regulation on the internet had been enacted namely Information and Electronic Transaction Law which aims to reduce and mitigate the spread of radicalism in Indonesia through cyberspace. Besides that the Government is also preparing regulations so that social media in the form of Facebook, Instagram, Twitter, and Youtube can be subject to sanctions in the form of fines or penalties in order to eradicate the content on the internet that can be categorized as the spread of false news or the spread of radical ideas. The programs from the government should be disseminated to the community to prevent the widespread of the radical idea that can persuade anyone, including a teenager to become radicalist that endanger the national security and peace in Indonesia, therefore this crime of terrorism constitutes as an extraordinary crime that takes the life of innocent people.

In addition, the government of Indonesia also has a collaboration with other countries to reduce or even eliminate radicalism contents on the internet that can cause people to be affected. This is considering that activities in the cyberspace is a borderless global domain, does not require much space, and timeless so that this brings new challenges in the current era of information globalization.Moreover, in preventing and overcoming cyber terrorism crimes, cooperation is needed in the development of Cyber Security frameworks among countries. In the ASEAN scope of cooperation, it has been agreed the ASEAN Plan of Action (PoA) has been established to prevent and counter the rise of radicalism and violent extremism. This collaboration aims to strengthen closer cooperation between ASEAN countries in preventing and counteringthe rise of radicalization and violent extremism.

\section{REFERENCES}

[1] Agus Surya Bakti. 2016. Deradikalisasi Dunia Maya. Jakarta : Daulat Press,

[2] Dokumen UNODC, The Use of the Internet for Terrorist Purposes, (UNODC, 2012)

[3] Jajang Jahroni, dan Jamhari Makruf (Ed). 2016.Memahami Terorisme : Sejarah, Konsep, dan Model,Jakarta : Pusat Pengkajian Islam dan Masyarakat UIN SyarifHidayatullah

[4] Seib, Philip and Dana M. Janbek. 2012. Global Terrorism and New Media: The Post Al-Qaeda Generation. New York :Roudledge

[5] Weimann, Gabriel. 2006.Terror on the Internet: The New Arena, the New Challenges, United States : United States Institute of Peace.

[6] Anonym, 'BNPT Minta Kominfo Blokir 22 Situs Radikal', <https://kominfo.go.id/index.php/content/ detail/4627/BNPT+Minta+Kominfo+Blokir+22+Situs+Radikal/0/berita-satker>, (accessed November 27th, 2018)

[7] Anonym, 'Riset Kominfo dan UNICEF Mengenai Perilaku Anak dan Remaja dalam Menggunakan Internet', <http://kominfo.go.id/index.php/content/detail/3834/Siaran+Pers+No.+17-PIH-KOMINFO-2-2014+tentang+

Riset+Kominfo+dan+UNICEF+Mengenai+Perilaku+Anak+dan+Remaja+Dalam+Menggunakan+Internet>”. (accessed Juli 25th 2018).

[8] Anonym, 'Pengertian Hoax dan Asal Kata Hoax',<https://lenterakecil.com/pengertian-dan-asal-katahoax/> (accessed May 24 2019)

[9] Anonym, 'Ini Cara Mengatasi Berita Hoax di Dunia Maya', https://kominfo.go.id/content/detail/8949/inicara-mengatasi-berita-hoax-di-dunia-maya/0/sorotan_media, (accessed Juni 25th 2018).

[10] Anonym, 'Pemerintah Blokir Ribuan Situs Radikal', <https://www.validnews.id/Pemerintah-BlokirRibuan-Situs-Radikal-cCk>, (accessed January 16th 2019)

[11] Amien Rais, 'Hadapi Terorisme dengan Cerdas',<http://ahmad.web.id/sites/kolom_amien_rais/20021031105455.shtml>, (accessed October 29th 2018) 
[12] Bagus Ramadhan,'Inilah Perkembangan Digital Indonesia tahun 2018', https://www.goodnewsfrom indonesia.id/2018/02/06/inilah-perkembangan-digital-indonesia-tahun-2018, (accessed September 28th 2018)

[13] Fatimah Kartini Bohang, 'Berapa Jumlah Pengguna Internet di Indonesia?', https://tekno.kompas.com/ $\mathrm{read} / 2018 / 02 / 22 / 16453177 /$ berapa-jumlah-pengguna-internet-indonesia, (accessed January 27th 2019)

[14] Harso Kurniawan, '2018 Pengguna Smartphone Capai 100 Juta Orang', <https://id.beritasatu.com/home/ 2018-pengguna-smartphone-capai-100-juta/176965>, (accessed January 17th 2019)

[15] Anonym,'Paham Radikal Tersebar lewat Berita Bohong', Kompas Newspaper, May 19th 2017, p.4

[16] Anonym, 'Agus SB : Teroris Merambah Dunia Maya',Kompas Newspaper, May 22th 2018, p.4

[17] Santha Oktabriancha, 'Mengenal Citizen Journalism (Jurnalisme Warga)', https://www.kompasiana.com/ santhabriancha/58ca972e729373722f0e2a8c/mengenal-citizen-journalism-jurnalisme-warga. (accessed Desember 27 2018)

[18] Budi Mulyana. 2013. 'Terorisme Internasional : Agenda Propaganda, Amerika Serikat dan Pandangannya Menurut Islam', Jurnal Ilmiah Ilmu Politik dan Komunikasi, Vol.2

[19] Panji Futuh Rahman. 2016. 'Penerapan Materi Deradikalisasi untuk Menanggulangi Radikalisme'. Jurnal TARBAWY, Vol.3 No.2, .

[20] Rudy AgusGemilangGultom, AsepAdangSupriyadi, andTatanKustana. 2018.'Strengthening ASEAN Cyber Cooperation in Countering Cyber Terrorist Groups Activities on the Internet by Implementing the Six-Ware Cyber Security Framework'.International Journal of Management and Information Technology, Vol 13 Issue 1,

[21] Zulfadli. 2017. 'Radikalisme Islam dan Motif Terorisme di Indonesia'. Jurnal Akademika, Vol.22 No.1.

\section{AUTHORS' BIOGRAPHY}

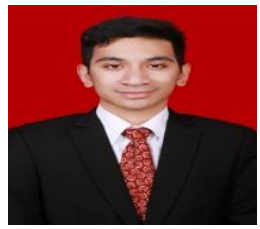

SYARIF SADDAM RIVANIE PARAWANSA. Was born in Surabaya, October 16, 1991. He is earned Bachelor Degree (SH) in Faculty of Law, Hasanuddin University, Makassar, 2013, and Masterr Degree (MH) in Faculty of Law, Hasanuddin University, Makassar, 2015. Currently he is a Student Doctoral Program (DR), Faculty of Law, Airlangga University, Surabaya since 2016.

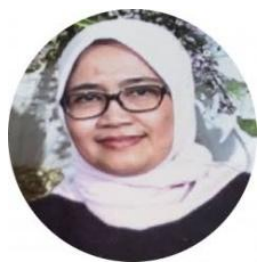

KOESRIANTI. She is earned Bachelor Degree (SH) in Airlangga University, Surabaya, Master (LL.M) and Ph.D Degree in New South Wales, SydneyAustralia. Once served as Head of Department of International Law and also Vice Dean for Finance, Faculty of Law, Airlangga University. Currently she is Senior Lecturer (Assoc.Professor) at Department of International Law, Airlangga University, Surabaya Indonesia and she is currently also as a Member of the Faculty Advisory Board, Faculty of Law, Airlangga University, Surabaya.

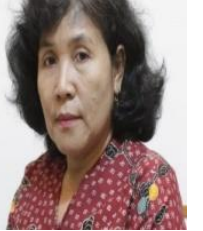

Toetik Rahayuningsih. She is earned Bachelor Degree (SH) in Airlangga University, Surabaya, Master Degree (M.Hum) in Diponegoro University, Semarang, and Doctoral Program (DR) in Airlangga University. Surabaya. Currently she is Senior Lecturer (Assoc.Professor) at Department of Criminal Law, Airlangga Universty, Surabaya, Indonesia.

Citation: Syarif Saddam RivanieParawansa, et.al. "Prevention of Radicalism in the Cyberspace in Indonesia". International Journal of Humanities Social Sciences and Education (IJHSSE), vol. 6, no.7, 2019, pp. 63-72. doi: http://dx.doi.org/10.20431/2349-0381.0607007.

Copyright: () 2019 Authors. This is an open-access article distributed under the terms of the Creative Commons Attribution License, which permits unrestricted use, distribution, and reproduction in any medium, provided the original author and source are credited. 